\title{
Bank Modelling Methodologies: A Comparative Non- Parametric Analysis of Efficiency in the Japanese Banking Sector.
}

\author{
Leigh Drake $^{a}$, Maximilian J. B. Hall ${ }^{b}$ and Richard Simper ${ }^{b *}$ \\ ${ }^{a}$ Nottingham University Business School, Jubilee Campus, Wollaton Road, \\ Nottingham, UK, NG8 1BB, ${ }^{b}$ Department of Economics, Loughborough University, \\ Ashby Road, Loughborough, UK, LE11 3TU
}

\begin{abstract}
This study examines the efficiency of the Japanese banking system utilising the relatively new, non-parametric, Slacks-Based Measure (SBM) technique by Tone (2001). This technique differs from the frequently used Banker, Charnes and Cooper (1984) Data Envelopment Analysis model in that it utilises information concerning slacks which do not feature in the latter's primal programme. In addition, we also extend the comparative bank modelling methodology literature by utilising both the Intermediation and Production approaches, together with a third methodology, the Profit / Revenue-based approach, based on a preferred methodology proposed in Berger and Mester (2003). We find that, across the three methodologies, there are marked differences in: mean efficiency scores; the dispersion of efficiency scores; and the ranking of banks and bank sectors. Hence, the results demonstrate a very high degree of modelling dependence, which, we argue, has important implications in the context of policy responses.
\end{abstract}

KEYWORDS: Efficiency; Slacks-Based DEA; Japanese Banking; Intermediation Approach; Production Approach; Profit / Revenue Approach.

JEL: C14, G2, L1.

\footnotetext{
${ }^{*}$ Corresponding author. Tel +44 (0)1509 222732. Fax: +44 (0) 1509 223910, E-Mail: r.simper@lboro.ac.uk.
}

The Financial support of the Japan Society for the Promotion of Science/British Academy is gratefully acknowledged. 


\section{INTRODUCTION.}

Since the bursting of the asset price bubble in the late-1980s, the Japanese banks have faced a number of serious problems. These comprise, inter alia (Hall, 1999a, IMF, 2003): weakness in the domestic economy, ${ }^{1}$ reversal of which is hampered by the limited remaining scope for manoeuvre available to the government given that nominal interest rates have been held at around zero per cent for a number of years now and the public finances are at crisis point (Hall, 2003a); continuing weakness in the domestic property market (both commercial and residential); weakness in the Japanese stock market; ${ }^{2}$ continuing excess capacity in the banking sector (despite some exit); low profitability; and persistent deflation, ${ }^{3}$ which exacerbates the corporate sector's ability to service its debts and raises the government's real debt burden. In addition, to this list must be added the internal management failings which have allowed the industry to be brought to its knees, the flawed corporate governance arrangements which have contributed to the banks' malaise, and the inadequate external oversight exercised by the supervisory authorities (Hall, 2003b).

Notwithstanding these long-standing problems, however, there are tentative signs that the banks' fortunes may be improving, in part due to the opportunities presented by the programme of "liberalisation and deregulation" instituted since the 1980s (Hall,

\footnotetext{
${ }^{1}$ Data released in 2004, however, suggested sustainable recovery may now be in place. Real GDP was shown to have grown by $3.2 \%$ ( $2 \%$ under the new methodology for measuring GDP adopted in November 2004) in fiscal 2003 with nominal GDP growing by $0.7 \%$ during the same period, , the first positive annual growth rate recorded for three years. Equally reassuring was the revelation that the expansion was fuelled not only by an expansion in exports but also by growth in domestic consumer demand. Together with other figures showing a rise in corporate profitability, declining corporate bankruptcies and a fall in unemployment commentators are finally suggesting the real economy may have turned the corner after a number of "false dawns" since the latter part of the 1990s.

${ }^{2}$ Although there has been a strong market recovery since the end of fiscal 2002, taking the Nikkei 225 index back above the 10,000 level (compared with a peak of around 40,000 recorded in the late 1980s) and the Topix index back above the 1,000 level. At the close of business on 13 January 2005 the Nikkei 225 stood at 11,453 and the Topix index at 1148.

3 There are some signs, however, that the worst may be over with the Bank of Japan forecasting a return to inflation, albeit of only 0.1 per cent, for the Consumer Price Index in fiscal 2005 after seven years of deflation.
} 
1998a, Chapter 4). ${ }^{4}$ This first became evident from the release of the banks' interim results for the period to end-September 2003 which showed that the big four ${ }^{5}$ banking groups had each returned to the black, reporting positive net profits for the first time in three years. The turnaround, which saw the major banks' combined net income rise to $¥ 921$ billion from a net loss of $¥ 16$ billion a year earlier, was mainly due to the stock market rally noted earlier and the economic recovery, which led to a drop in non-performing loans (NPLs) ${ }^{6}$ (though, in part, this was due to debt forgiveness) and lower "credit costs". Despite the evident improvement, however, which led each of the 'big 4' to forecast full year profits for fiscal 2003, ${ }^{7,8}$ things remain bleak: core profitability remains weak; no significant expansion in lending margins was achieved; the demand for loans remains sluggish (bank lending has fallen for seven consecutive

4 Although this creates something of a "double-edged sword" for most banks, as it opens up traditional markets to competitors as well as providing new opportunities - the biggest "losers" were always going to be the Long-Term Credit Banks given the undermining of their limited franchise (Hall, 1998b and 1999b), a view endorsed by the subsequent nationalisation of the Long-Term Credit Bank (now called the Shinsei Bank) and the Nippon Credit Bank (now known as the Aozora Bank) in 1998 - the benefits are now beginning to materialise. These have arisen, in particular, because of the gradual extension of the scope of permissible business activities allowing for deeper penetration of the securities and insurance markets.

5 The Resona Holdings group was the exception but hardly surprisingly so given the government's rescue of Resona Bank in May 2003 through a capital injection of $¥ 1.96$ trillion. This controversial rescue - the bank was found to be insolvent in October 2003 and many believe that the authorities knew it was insolvent at the time of the rescue - followed the FSA's declaration that the bank was undercapitalised (its auditors refused to recognise more than three years of Deferred Tax Assets as capital, resulting in the capital adequacy ratio falling to around 2 per cent, well below the 4 per cent minimum required of 'domestic' bank operators in Japan) but solvent.

6 Using the Financial Reconstruction Law definition of NPLs (Hall, 2003b), the banking sector's outstanding NPLs amounted to $¥ 35.3$ trillion at end-March 2003, with the 'major banks' contributing $¥ 20.9$ trillion to the total (Bank of Japan, 2003).

7 Although UFJ Holdings subsequently announced (in May 2004) that it would make a net loss of at least $¥ 300$ billion in fiscal 2003, largely due to higher-than-expected loan loss reserves. This downward revision of its profits forecast, taken after heeding the advice of its external auditors, followed an earlier downwards revision announced in April 2004 to take account of the higher loan loss provisioning necessitated by an FSA inspection.

8 In the event, five of the top seven banking groups posted profits for fiscal 2003; the odd ones out were UFJ Holdings and Resona Holdings. Mitsubishi Tokyo Financial Group posted the largest net profit, of $¥ 561$ billion, followed by the Mizuho Financial Group ( $¥ 407$ billion) and SMFG ( $¥ 330$ billion). UFJ's net loss came in at $¥ 402$ billion, compared with Resona’s net loss of $¥ 1.66$ trillion. 
years); gross fee and commission income ${ }^{9}$ remains at around 17 per cent of operating income, compared with figures of around 30 per cent for US banks; NPLs still average around 6.5 per cent of total loans for the big banks; no generalised recovery in land prices is in sight; the corporate sector remains in a precarious financial position; when deferred tax assets are stripped out, most, if not all, banks are exposed to be seriously under-capitalised; and most banks are still believed to be underprovisioned and overstating the value of the collateral backing their loans, thereby inflating stated profitability. It will therefore be some time yet before the Japanese banking industry becomes rehabilitated and ready to face once again the competition in today's global banking industry.

Due to the arguments presented above and in greater detail in Section 2 below, it is not only important to assess the efficiency of Japanese banks over the tumultuous period outlined, but also to ensure that the analysis is coherent and unaffected by the particular input-output specification. The aim of this paper, therefore, is to present results on the Japanese banking industry and determine whether efficiency has changed over an eight year period; we also examine whether changes in balance sheet composition, operating costs and profit and loss accounting have had an effect. That is, we extend the literature by considering three different approaches to the input/output specification in bank efficiency modelling, namely, the Intermediation, Profit / Revenue and Production approaches. The first mentioned was developed by Sealey and Lindley (1977), the Profit / Revenue approach has been advocated by Berger and Mester (2003), while the last mentioned was based on the arguments initially developed by Benston and Smith (1976) and elaborated further by Berger and Humphrey (1991).

In their comparative study, Berger and Mester (1997) advocate a Profit / Revenue-based approach by stating that "the profit efficiency concept is superior to the cost efficiency concept for evaluating the overall performance of the firm. Profit efficiency accounts for errors on the output side as well as those on the input side, and some prior evidence suggested that inefficiencies on the output side may be as large or larger than those on the input side. Profit efficiency is based on the more accepted economic goal of profit maximisation, which requires that the same amount of

\footnotetext{
9 This derives from syndicated lending (growth in which the Bank of Japan has sought to promote by publishing relevant data on its website since December 2003), asset management and investment banking activities as well as the sale of retail investment products.
} 
managerial attention be paid to raising a marginal dollar of revenue as to reducing a marginal dollar of costs” (Berger and Mester, 1997, p. 900).

It is acknowledged, however, that hitherto the Intermediation and Production approaches have constituted the main research methodologies in respect of bank efficiency measurement. The key difference between the two main modelling methodologies is that the Intermediation approach considers outputs to be financial earning assets and inputs as liabilities and labour and physical capital; whereas the production approach considers both financial earning assets and liabilities (deposits) as outputs. However, there is still no current consensus on which of the three methodologies outlined above should be utilised in bank efficiency analysis. For example, the Intermediation approach has been recently modelled by Altunbas et al (2001), Drake and Simper (2002), and Mertans and Urga (2001); and the Production approach by Cavallo and Rossi (2001), Chaffai et al (2001), Limi (2004) and LozanoVivas et al (2002). However, using either of these specifications could result in different policy outcomes based on the efficiency measures obtained. Tortosa-Ausina (2002), for example, found that the Intermediation approach generally gives lower overall efficiency scores than the Production approach. Furthermore, in respect of the Intermediation approach the authors conclude that, "by ignoring payment, liquidity, and safe keeping services (measured by deposits), important firm/business lines are ignored. Disregarding this output category could therefore lead to a biased appraisal of the banking industry in which it seems that some firms cluster together” (page 210).

Hence, an aim of this paper is to determine whether there are important differences in efficiency results when these alternative methodological approaches are utilised. However, in the spirit of recent research by Berger and Mester, we maintain that the Profit / Revenue based approach is likely to offer the most comprehensive analysis of bank efficiency. In their recent investigation of the causes of the recent changes in the performance of US banks, for example, Berger and Mester (2003) found that "banks tried to maximise profits by raising revenues as well as reducing costs. Over time, banks have offered wider varieties of financial services and provided additional convenience. These additional services, or higher service quality, which are difficult to control for in cost and profit functions, may have raised costs but also raised revenues by more than these cost increases” (ibid., pages 29-30). 
Furthermore, they conclude that "methods that exclude revenues may be misleading” (page 1).

While Berger and Mester (2003) adopted this more comprehensive approach to performance analysis in the context of the parametric stochastic frontier approach, it is evident that a DEA specification which includes physical units or cost proxies as inputs and balance sheet asset items (and liabilities in the case of the Production approach) as outputs would therefore be potentially misleading by virtue of the exclusion of revenue effects. Although Drake, Hall and Simper (2005) have utilised this more comprehensive Profit / Revenue based approach in the context of a nonparametric (DEA) analysis of the efficiency of the Hong Kong banking sector, such an approach has not been widely used in banking. Cummins et al (2004), however, recently estimated revenue as well as production and cost frontiers for the Spanish insurance industry using DEA.

Hence, this paper represents one of the first attempts (to the authors' knowledge) to contrast this Profit / Revenue-based approach with the alternative Intermediation and Production approaches using the non-parametric efficiency methodology. Indeed, we extend the non-parametric analysis within the banking literature by utilising the relatively-new Tone (2001) Slacks-Based Measure (SBM), which explicitly incorporates the slacks in the primal function of the non-parametric program. As discussed in detail in Section 3, the Tone measure differs from the more usual Banker, Charnes and Cooper (BCC, 1984) non-parametric program by ensuring that slacks are explicitly taken into account in the efficiency analysis. Examples of banking studies using the BCC program include Drake and Hall (2003), Tsionas et al (2003), and Chu and Lim (1998)).

The paper is organised as follows. In Section 2 we discuss the changing nature of the Japanese banking industry with respect to our sample period, 1995-2002. In this time the banking industry has seen different sectors expand and contract as business conditions changed dramatically due to mainly domestic factors, such as the financial crisis and deregulation. Section 3 provides a brief review of the empirical literature relating to Japanese bank efficiency. The methodology and data utilised to estimate the three models - Intermediation, Production and Profit / Revenue - based approaches - are discussed in Section 4. Section 5 presents the empirical results and analysis. Finally, Section 6 concludes. 


\section{THE JAPANESE BANKING SECTOR.}

\subsection{Classification of depository institutions}

Apart from the public sector-owned postal network - "Japan Post" - the biggest deposit-taking organisation in the world, a number of privately-owned depository institutions operate in Japan. These are separated into banks proper and cooperative type institutions - see Table 1. The “banking group” comprises 'City Banks', 'Regional Banks', 'Second Association Regional Banks', foreign banks, 'Long-Term Credit Banks', 'Trust Banks' and 'other' banks; whilst the cooperative grouping includes, inter alia, 'Shinkin Banks', 'Credit Cooperatives', 'Agricultural Cooperatives', 'Fishery Cooperatives' and their National Federations. ${ }^{10}$

Within the bank grouping, institutions are further sub-divided into 'Ordinary Banks' and 'Specialised Long-Term Financial Institutions', although recent financial liberalisation (see below) has served to erode somewhat the strict traditional business demarcations. All ordinary banks operate in accordance with the Banking Law of 1981 (as subsequently amended by the 1992 and 1998 revisions) and under license from the Financial Services Agency (FSA). Although their primary focus is on the provision of short-term financing facilities, especially in the form of deposits, loans and funds transfer, they are also engaged today in medium- and long-term finance with both corporations (of all sizes) and individuals. Many are also substantial operators in international markets, although, since the bursting of the asset bubble in the late eighties, overseas operations have been scaled back by the majority.

The first group of ordinary banks, the City Banks, are typically large-scale operators in both domestic and international markets, with nationwide branch networks at home and their headquarters sited in the major cities. Traditionally, they have been the major suppliers of short-term finance to large corporations but, with the development of securities markets in Japan (Hall, 1998a, Chapter 3), have been forced to court SMEs and retail customers more actively. Liberalisation (see below) has also

10 The Shinkin Central Bank, formerly known as the Zenshinren Bank, is the national federation of shinkin banks; the Rokinren Bank is the central national organisation for labor banks; and the Norinchukin Bank is the central cooperative bank for the agriculture, forestry and fisheries industries. [For further details of the operations of these and other specialist cooperative-type institutions see Japanese Bankers' Association, 2001, Chapter 1.] 
allowed them to diversify more widely into securities and insurance business; and the growth in derivatives activities in Japan has provided further business opportunities in the last few years.

The Regional Banks constitute the second grouping of ordinary banks. They can be distinguished from the City Bank grouping by virtue of their smaller scale of activity and greater geographical concentration of business, typically focussing their operations on SMEs and individuals residing in the prefecture within which they are headquartered. As a group, they are also major providers of funds to the call and bill money markets (Hall, ibid.).

The third group of ordinary banks, the Second Association Regional Banks, are also distinguished by the strength of their regional ties and the degree of geographical concentration of their business activities. The main difference with the regional banks lies in their reduced scale of activities and this is due, in part, to the fact that the majority are converted mutual banks which ceased to exist as a distinct class of bank in 1993.

The fourth and final grouping of banks classified as ordinary banks are the foreign banks. Traditionally focussed on foreign trade financing and foreign currency transactions, liberalisation has forced them to look elsewhere for their salvation, leading them to develop off-balance-sheet trading activities and to diversify into risk management, advisory services and derivatives operations.

\section{INSERT TABLE 1}

As for the 'Specialised Financial Institution' category of bank, the Long-Term Credit Banks and the Trust Banks jointly make up the so-called 'Long-Term Financial Institutions'. These are distinct from the other specialist depository institutions, the cooperatives, which are all non-profit-making organisations. The Long-Term Credit Banks, of which there are now only two following the Industrial Bank of Japan's decision to become part of Mizuho Holdings in September 2000 (see below), operate in accordance with the Long-Term Credit Bank Law of 1952. They were originally established to clearly differentiate the provision of short-term from long-term finance and to lighten the ordinary banks' burden in respect of the supply of long-term financing. Their funding activities are also distinguishable from those of ordinary banks by virtue of their greater ability to issue debentures (liberalisation has, however, 
reduced this comparative advantage) and the restrictions imposed on their deposittaking - they can only accept deposits from their borrowers and the purchasers of their debentures. The other group of specialist long-term financial institution, the trust banks, comprises institutions which are allowed to concurrently engage in ordinary banking and trust banking. The initial governing legislation was provided by the 'Law Concerning the Joint Operation of Ordinary Banks, Savings Bank Business and Trust Business' of 1943, but this was subsequently revised in 1981 and, more recently, in 1992 under the 'Financial System Reform Law' (see below). The last piece of legislation has led to a dramatic growth in the number of trust banks operating in Japan (there were only 16 in existence in 1990) as newly-established entities now operate alongside those set up prior to 1960 and the nine locally-incorporated foreign bank subsidiaries approved in 1985.

\subsection{Recent consolidation amongst the major banks}

In a bid to cut costs and improve operating efficiency, a wave of consolidation has swept across the City Bank sector of the banking industry. This has resulted in their numbers falling from 13 in 1990 to just $7^{11}$, with $5^{12}$ major banking groups now dominating the banking scene in Japan - see Table 2. These groups typically include both a city bank and a trust bank and, in the case of Resona Holdings, regional banks also.

\section{INSERT TABLE 2}

Nor have the other sub-sectors escaped the chill winds of changes. For example, although the number of regional banks in existence has remained constant since 1991 - notwithstanding the nationalisation of the Ashikaga Bank in December $2003^{13}$ - the

11 Comprising the Bank of Tokyo-Mitsubishi, Mizuho Bank, Mizuho Corporate Bank, Resona Bank, Saitama Resona Bank, UFJ Bank, and Sumitomo Mitsui Banking Corporation.

12 Comprising Mizuho Holdings, the Sumitomo Mitsui Financial Group, the Mitsubishi Tokyo Financial Group, UFJ Holdings and Resona Holdings.

13 The bank, which was Japan's tenth largest regional lender, was nationalised following the bank's auditors' decision not to allow the bank to count any of its deferred tax assets (which amounted to 186 
number of Second Association Regional Banks contracted sharply from 68 to 53 over the same period as a result of mergers. In addition, despite the deregulation - induced growth in trust bank numbers noted earlier, several mergers have also occurred in this sector. $^{14}$

The banking system in Japan is therefore an extremely interesting sector to analyse given the substantial changes that have occurred over the last 10 years. The Japanese banking system gives us, therefore, an ideal basis to determine whether efficiency scores and rankings are affected within a single market due to different bank modelling methodologies. Indeed, if it is established that there are substantial differences, then this has important implications, as it needs to be decided which of these alternative methodologies provides the better guide for government policy in the context of achieving the aim of stability and effectiveness of the banking industry in Japan. The next section provides a brief review of the previous empirical literature relating to the efficiency of the Japanese banking system.

\section{BRIEF LITERATURE REVIEW}

Given the problems experienced by the Japanese financial system (and banks in particular) in recent years, and the recent pressures for consolidation, surprisingly little academic research has been undertaken into the costs and efficiency of Japanese banks. This contrasts markedly with the wealth of research into the performance of US financial institutions, for example.

Tachibanaki et al (1991) estimated a two output translog cost function using a sample of 61 banks between 1985 and 1987 and found evidence of economies of scale for all sizes of banks in all three years of the study. It is interesting to note, in the

per cent of Tier 1 capital) as capital, causing its capital adequacy ratio to fall to -3.7 per cent at endSeptember 2003 [the minimum required of "domestic" operators is 4 per cent]. Liabilities were also found to have exceeded assets by $¥ 102$ billion. The nationalisation route, rather than allowing outright failure, was adopted because of concerns for the regional economy as the bank accounted for nearly 50 per cent of bank lending and deposits in its home prefecture of Tochigi.

${ }^{14}$ For example, in April 2000, the Mitsui Trust and Chuo Trust merged to form the Chuo Mitsui Trust, which went on to merge with Sakura Trust in February 2002 to form the Mitsui Trust Holdings. Similarly, three trust banks - Mitsubishi Trust, Nippon Trust and Tokyo Trust - were merged to create the Mitsubishi Trust in October 2001. 
context of the current paper, that the outputs were proxied by revenues produced from earning assets.

Fukuyama (1993) used the non-parametric technique, DEA, to analyse the overall technical efficiency (OE) of Japanese commercial banks and to decompose this into its two constituent components, pure technical efficiency (PTE) and scale efficiency (SE). The cross section sample consisted of 143 banks for the financial year 1990/91. The mean level of OE for the whole sample was found to be 0.8645 which, compared to a maximum level of unity, implies that banks could, on average, have produced the same levels of outputs with around 14\% less resources or inputs. Unlike other studies, Fukuyama found evidence of only mild economies of scale with the mean level of SE being 0.9844. Hence, most of the observed inefficiency was associated with pure technical (mean PTE score, 0.8509), rather than scale inefficiency.

McKillop et al (1996) used the composite cost function developed by Pulley and Braunstein (1992) to analyse costs and efficiency in giant Japanese banks. The data related to annual data from 5 very large Japanese City Banks over the period 1978 - 91 and McKillop et al used the intermediation approach in a three output, three input model. The specification of a composite cost function facilitated the estimation of four model variants, including the Translog and Generalised Translog. However, for all the models estimated, McKillop et al find evidence of statistically significant economies of scale for all banks at the sample mean. Furthermore, the estimated values of the economies of scale parameter were found to range between 1.08 and 1.28 (indicating economies of scale), very similar to the values found by Tachibanki et al (1991).

Altunbas et al (2000) utilise the hybrid Fourier/Translog cost function/frontier outlined previously to investigate both scale economies and X-efficiencies in Japanese banking. They specify 3 outputs (total loans, total securities and off-balance sheet items) and 3 inputs (labour, capital and total funds). In addition to the usual cost function specification, however, Altunbas et al also test for the impact of risk and quality factors on costs, scale economies and X-efficiency. The ratio of loan-loss provisions to total loans is included in the cost frontier to capture loan quality while risk is modelled via the inclusion of financial capital and the ratio of liquid assets to total assets. The incorporation of risk and quality factors is clearly potentially very important given the recent banking crisis in Japan. It should be noted, however, that 
Japanese banks were renowned for concealing the true scale of their bad debt problems for a number of years during the 1990s (Hall, 2000).

The sample consists of around 136 Japanese banks and covers the years 1993 to 1996. Furthermore, Altunbas et al allow for the possibility of technical change over the period via the inclusion of a simple time trend. Altunbas et al find that economies of scale in Japanese banking tend to be overstated when risk and quality factors are not incorporated, particularly for the larger banks. Specifically, they find that "diseconomies of scale become much more widespread and optimal bank size falls from around $¥ 5-10$ trillion to $¥ 1-2$ trillion when risk and quality factors are taken into account”. X-inefficiencies are found to range between $5 \%$ and $7 \%$, in contrast the levels of around 20\% typically found in studies of US banks. Interestingly, the X-efficiency estimates are found to be much less sensitive to the exclusion of risk and quality factors than the economies of scale estimates. However, it should be noted that, in the context of the subsequent results, Altunbas et al focused solely on cost efficiency and also utilised the intermediation approach. This may provide a partial explanation for their finding of surprisingly low levels of $\mathrm{X}$ inefficiency in Japanese banking.

Finally, Drake and Hall (2003), using DEA on a 1997 cross-section sample, also find that the largest City banks exhibit clear evidence of decreasing returns to scale with a mean SE level of 91.27. They do, however, find evidence of considerable potential economies of scale for most banks as the mean level of SE for the overall sample is only 92.78, with the vast majority of banks exhibiting increasing returns to scale. In contrast to Altunbas et al (2000), Drake and Hall find an indicative MES in the total lending range of $¥ 6$ to $¥ 10$ trillion, which is relatively invariant to controlling for lending quality (via the inclusion of loan loss provisions). Furthermore, Drake and Hall also find that the measures of pure technical efficiency are more sensitive to the latter than are the scale economy measures.

Interestingly, Drake and Hall (2003) additionally find important efficiency differences across the various sub-sectors of Japanese banks. Specifically, the Trust banks and LTCBs are found to be by far the most efficient banking sectors in Japan. Both sectors exhibited mean SE and PTE scores of 100, in contrast to the sample mean levels of 92.78 and 78.11 respectively. Furthermore, this result pertains whether or not lending quality is controlled for. This is an interesting result in itself, but also in the context of the subsequent failures of a number of the LTCBs. The fact 
that most of these were associated with unrecorded bad debts appears to confirm that many banks continued to hide the true scale of their bad debt problems for long periods during the 1990s. Hence, any efficiency results for Japanese banks using official 1990s data may not be totally reliable, even if researchers control for risk and lending quality (using reported loan loss provisions). The results may also reflect the fact alluded to previously, however, that the major problem facing many Japanese banks was low profitability (and high bad debts) rather than high cost ratios. Hence, it is quite possible that the LTCBs and trust banks were highly cost efficient but nevertheless suffered from asset quality and profitability problems. This tends to reinforce the argument made by Berger and Mester (2003) that the Profit / Revenue approach may provide a more comprehensive analysis of banking efficiency, and this may be particularly relevant in the case of the Japanese banking sector.

The next Section details the data utilised in the three methodologies and also provides an introduction to the non-parametric, Tone (2001) Slacks-Based Measure.

\section{METHODOLOGY AND DATA.}

The non-parametric efficiency approach was originally developed by Farrell (1957) and later elaborated by Banker, Charnes and Cooper (BCC) (1984) and then by Fare, Grosskopf and Lovell (1985). The constructed relative efficiency frontiers are non-statistical or non-parametric in the sense that they are constructed through the envelopment of the Decision-Making Units (DMUs), with the "best practice” DMUs forming the non-parametric frontier. This non-parametric technique was referred to as “Data Envelopment Analysis” (DEA) by Charnes, Cooper and Rhoades (1978).

A particular advantage of non-parametric techniques such as DEA, relative to parametric techniques, such as stochastic frontier analysis (see Drake and Simper (2003) and Ferrier and Lovell (1990)), is that the latter must assume a particular functional form which characterises the relevant economic production function, cost function, or distance function. Hence, any resultant efficiency scores will be partially dependent on how accurately the chosen functional form represents the true production relationship (i.e., the relationship between inputs/resources and outputs). ${ }^{15}$

\footnotetext{
${ }^{15}$ For example, Functional Form dependence has been shown by McAllister and McManus (1993).
} 
As DEA is non-parametric and envelops the input/output data of the DMUs under consideration, the derived efficiency results do not suffer from this problem of functional form dependency. Examples of DEA applied to the analysis of banking include Bauer et al (1998), Tortosa-Ausina (2002) and Maudos and Pastor (2003).

The vast majority of DEA studies of banking, however, do not explicitly account for slacks in the relative efficiency analysis. As Fried et al (1999) point out: "The solution to the DEA problem yields the Farrell radial measure of technical efficiency plus additional non-radial input savings (slacks) and output expansions (surpluses). In typical DEA studies, slacks and surpluses are neglected at worst and relegated to the background at best.” (P 250)

Such output and input slacks are essentially associated with the violation of neoclassical assumptions. If we take the standard input-oriented DEA approach, for example, input slacks would be associated with the assumption of strong or free disposability of inputs which permits zero marginal productivity of inputs and hence extensions of the relevant isoquants to form horizontal or vertical facets. In such cases, units which are deemed to be radial or Farrell efficient (in the sense that no further proportional reductions in inputs is possible without sacrificing output), may nevertheless be able to implement further additional reductions in some inputs. Such additional potential input reductions are typically referred to as non-radial input slacks, in contrast to the radial slacks associated with DEA or Farrell inefficiency, i.e., radial deviations from the efficient frontier.

Hence, units with excessive usage of some inputs (as measured by the nonradial input slacks) would be deemed to be efficient according to the standard BCC DEA analysis. If slacks were explicitly incorporated into the relative efficiency analysis, however, such units could actually be found to be highly inefficient. Furthermore, it could be argued that explicitly incorporating input slacks in the efficiency analysis could be particularly important in the context of Japanese banking. Firstly, as is discussed in further detail below, loan loss provisions are treated as an input / cost in the subsequent DEA analysis. Given the severe problems experienced by Japanese banks in the context of bad debts and non-performing loans (Hall, 2003b), however, many banks are likely to have very large loan loss provisions in particular years. Hence, the possibility arises that some banks could be deemed efficient if input slacks in the context of this particular input are not explicitly accounted for. 
Similarly, a further feature of the crisis in Japanese banking since the mid1990s has been the dramatic contraction in bank lending. This, combined with the well-documented tendency towards "labour hoarding” in the Japanese economy, may imply that the decline in employment in Japan will not always have been commensurate with the decline in banking activity. Once again, this may be revealed in the form of the excessive use of the labour input (and excessive labour costs) and hence in the relevant input slacks.

For the reasons outlined above, therefore, we feel it is appropriate to utilise the slacks-based measure (SBM) for DEA recently proposed by Tone (2001). This SBM approach specifically incorporates slacks in the objective function. Furthermore, as with the BCC approach, the efficiency scores are reference set dependent. An exposition of the SBM approach is provided below.

Given a set of inputs $\mathrm{X}=\left(\mathrm{x}_{\mathrm{ij}}\right) \in \mathfrak{R}^{\mathrm{m} \times \mathrm{n}}$ and outputs $\mathrm{Y}=\left(\mathrm{y}_{\mathrm{ij}}\right) \in \mathfrak{R}^{\mathrm{s} \times \mathrm{n}}$, the slacks from a DEA-based program which can be written as, $\mathrm{x}_{0}=\mathrm{X} \lambda+\mathrm{s}^{-}$and $\mathrm{y}_{0}=\mathrm{Y} \lambda+\mathrm{s}^{+}$, with $\lambda \geq 0, \mathrm{~s}^{-} \geq 0$, and $\mathrm{s}^{+} \geq 0$, where $\mathrm{s}^{-}$and $\mathrm{s}^{+}$are the input and output slacks respectively. The SBM linear program for $\lambda, \mathrm{s}^{-}$and $\mathrm{s}^{+}$is given by the following expression:

$$
\begin{array}{ll}
\min & \tau=\mathrm{t}-\frac{1}{\mathrm{~m}} \sum_{\mathrm{i}=1}^{\mathrm{m}} \mathrm{S}_{\mathrm{i}}^{-} / \mathrm{x}_{\mathrm{io}} \\
\text { subject to: } \quad & 1=\mathrm{t}+\frac{1}{\mathrm{~s}} \sum_{\mathrm{r}=1}^{\mathrm{s}} \mathrm{S}_{\mathrm{r}}^{+} / \mathrm{y}_{\mathrm{ro}} \\
& \mathrm{tx}_{\mathrm{o}}=\mathrm{X} \Lambda+\mathrm{S}^{-} \\
& \mathrm{ty}_{\mathrm{o}}=\mathrm{Y} \Lambda-\mathrm{S}^{+}
\end{array}
$$

where $\Lambda=\mathrm{t} \lambda \geq 0, \mathrm{~S}^{-}=\mathrm{ts}^{-} \geq 0$, and $\mathrm{S}^{+}=\mathrm{ts}^{+} \geq 0$. The optimal solution is when $\tau=1$ and hence a DMU will have zero input and output slacks and be fully efficient on the frontier. ${ }^{16}$ That is, to be SBM-efficient also implies BCC efficiency and this is known as Pareto-Koopmans efficiency. Conversely, for inefficient DMUs, the SBM relative efficiency scores must be lower than, or equal to, the BCC scores by

\footnotetext{
16 The results for program (2) were obtained from the DEA Solver professional program; see Cooper, Seiford and Tone (2000).
} 
construction. To the authors' knowledge, little use has been made in banking studies to date of the Tone (2001) SBM DEA program.

In this study we present comparative results from the three main methodologies utilised in the literature to model bank efficiency; the Intermediation, Production and the Profit / Revenue-based approaches. ${ }^{17}$ The summary statistics are provided, according to bank sector type, in Table 3. In modelling the Intermediation approach we specify 4 outputs and 4 inputs (see Sealey and Lindley (1977)). The first output is 'total loans' (total customer loans + total other lending), the second output is 'other earning assets', the third output is 'net commission, fee and trading income', and the final output is 'other income'. The third and fourth outputs are included in the analysis to reflect the fact that banks around the world have been diversifying, at the margin, away from traditional financial intermediation (margin) business and into "off-balance sheet” and fee income business. Hence, it would be inappropriate to focus exclusively on earning assets as this would fail to capture all the business operations of modern banks. The inclusion of 'other income' is therefore intended to proxy the non-traditional business activities of Japanese banks (see Sections 1 and 2).

\section{INSERT TABLE 3}

The inputs estimated in the Intermediation approach are: 'total deposits' (total deposits + total money market funding + total other funding); 'total operating expenses' (personnel expenses + other administrative expenses + other operating expenses); 'total fixed assets'; and 'total provisions' (loan loss provisions + other provisions). Ideally, the labour input would be proxied either by number of employees or by personnel expenses. However, details on employment numbers are not available for all banks in the sample, while operating expenses data is not available on a disaggregated basis. Hence a 'total operating expense' variable was utilised.

With respect to the last-mentioned input variable, it has long been argued in the literature that the incorporation of risk/loan quality is vitally important in studies of banking efficiency. Akhigbe and McNulty (2003), for example, utilising a profit function approach, include equity capital "to control, in a very rough fashion, for the

\footnotetext{
17 The data was obtained from Bankscope and covers the sample period 1995 to 2002 utilising a balanced sample equal to 1109 banks in total and were deflated using the Japanese GDP deflator.
} 
potential increased cost of funds due to financial risk” (page. 312). Altunbas et al (2000) and Drake and Hall (2003) also find that the failure to adequately account for risk can have a significant impact on relative efficiency scores.

In contrast to Akhigbe and McNulty (2003), however, Laevan and Majnoni (2003) argue that risk should be incorporated into efficiency studies via the inclusion of loan loss provisions. That is, “following the general consensus among risk agent analysts and practitioners, economic capital should be tailored to cope with unexpected losses, and loan loss reserves should instead buffer the expected component of the loss distribution. Consistent with this interpretation, loan loss provisions required to build up loan loss reserves should be considered and treated as a cost; a cost that will be faced with certainty over time but that is uncertain as to when it will materialise” (page 181). Hence, we also incorporate provisions as an input/cost in the DEA relative efficiency analysis of Japanese banks (this is also consistent with Basel II (Basel Committee, 2004)).

Berger and Mester (2003) argue (in the context of a stochastic frontier approach) that "use of the profit approach may help take into account unmeasured changes in the quality of banking services by including higher revenues paid for the improved quality, and may help capture the profit maximisation goal by including both the costs and revenues" (page 80). Hence, the outputs estimated in this methodology are: 'net interest revenue’ (interest income - interest expenses); 'net commission, fee and trading income', and 'other income'. The inputs are: 'total other non-interest expenses' (personnel expenses + other administrative expenses); 'other operating expenses', and 'total provisions' (loan loss provisions and other provisions).

Finally, in the case of the Production approach, we have five outputs and three inputs. The outputs are: 'total customer loans' (customer loans + other lending); 'net commission, fee and trading income'; 'total deposits'; 'other earning assets'; and 'other operating income'. Ideally, a more appropriate measure of deposits to be used in the Production approach would be the number of deposit accounts. However, the required data for this specification was not available across the bank sample. The three inputs are: 'total other non-interest expenses' (personnel expenses + other administrative expenses); 'other operating expenses'; and 'total provisions' (loan loss provisions and other provisions). 


\section{RESULTS}

Table 4 provides a summary of the (pure technical) efficiency scores obtained under the three alternative methodologies, while a comparative analysis of the mean values of the efficiency scores across the different banking sectors is provided in Figures 1 to 3 for the Intermediation, Production, and Profit / Revenue-Based methodologies respectively. Finally, Figures 4 to 8 contrast the three alternative efficiency measures over the sample period for each bank type.

The most striking contrast between the three sets of efficiency scores apparent in Table 4 and Figures 1 to 3 is that the Intermediation approach consistently produces the highest relative efficiency scores, while the Production methodology consistently produces the lowest scores. This is in contrast to the finding of Tortosa-Ausina (2002) who found the reverse. This difference in results may be partially attributable to the fact that the latter study uses the BCC methodology, in contrast to the SBM approach utilised here.

\section{INSERT TABLE 4}

A further feature of the results is that the Intermediation approach tends to produce relatively little variation in efficiency scores through time, across sectors or across the sample as a whole, and this is particularly apparent in Figure 1. The mean efficiency scores for the sample as a whole, for example, vary between 96.38 in 1997 and 95.39 in 2001. Similarly, with the exception of 1998 (58.82), the minimum efficiency scores range between 91.61 in 1995 and 84.22 in 2002. Finally, with respect to the individual banking sectors, these scores range from 100 for the COOP banks (in 2000, 2001 and 2002) to 95.33 for the regional banks in 2001. Despite this lack of variation in efficiency scores, however, it is clear that the City and COOP bank sectors have tended to exhibit the higher mean efficiency scores over the sample, with the COOP bank sector performing particularly well since 2000.

In contrast, the mean (min) efficiency scores for the sample, according to the Production approach, range from 47.64 (10.18) in 2002 to 35.38 (9.55) in 1999, with the lowest (min) score of 7.63 being recorded in 1998. As with the Intermediation approach, however, the City and COOP bank sectors appear to out-perform the other 
bank sectors, although the contrast in relative efficiency performance is much more apparent under the Production approach. In 2002, for example, when the sample mean efficiency level is at its highest (47.64), the mean efficiency scores for the City and COOP bank sectors are 83.73 and 90.89 respectively. This contrasts with mean efficiency scores of 38.19 (MB2AR), 48.68 (Regional) and 57.27 (Trust) for other bank sectors.

Finally, the Profit / Revenue-based approach produces evidence of mean levels of inefficiency which vary between around 20 and 30 per cent. This contrasts with mean inefficiency levels of around 3 to 5 per cent according to the Intermediation approach and between 50 to 65 per cent according to the Production approach. Furthermore, it is clear from Figure 2 that the Profit / Revenue-based results show considerable variation, both through time and across the different banking sectors. With respect to the former, there appears to be a clear downturn in relative efficiency level during 1997 and 1998 and this is likely to be attributable to the home-grown financial crisis (Hall, 1999a) which in turn, was exacerbated by the S.E. Asian crisis, given the large exposure of Japanese banks to this region at the time. It is interesting to note, however, that this downturn is much more evident in the Profit / Revenue-based results than in either the Intermediation or Production approaches. Not surprisingly, Figure 2 indicates that all sectors exhibited a trend improvement in relative efficiency levels after 1998 and, as in the other results, this is most evident in respect of the City banks and, most especially, the Coop banks.

\section{INSERT FIGURES 1 - 8.}

If we now consider the results for the individual bank sectors in more detail, it is clear from Figures 4 to 8 that, while the mean levels of inefficiency are typically very different, the different methodologies often exhibit similar trends in efficiency levels over time. This is particularly true in respect of the Production and Profit / Revenuebased approaches. Figures 4 and 5, for example, illustrate very clearly that, according to these approaches, both the City and Coop bank sectors exhibit a clear improvement in relative efficiency levels from 1998 and 1999 respectively. It is also clear that there is a considerable degree of convergence between all three measures of relative efficiency by the end of the sample, although these figures do highlight the lack of discrimination / variation in the relative efficiency levels produced using the 
Intermediation approach. Given the problems experienced by the Japanese banking system over the sample period, and discussed in some detail in Section 2, one may well question the validity of a methodology which suggests that the vast majority of Japanese banks are, in relative terms, highly efficient, and where there is very little temporal variation in relative efficiency scores, even during a tumultuous period encompassing both a home-grown and S.E Asian financial crisis and their aftermath.

Figure 6 indicates that, aside from a moderate decline during 1997 and 1998, the MB2AR banks exhibit no obvious trends in relative efficiency levels over the period. This Figure does indicate very clearly, however, the marked contrast in the mean efficiency levels produced by the alternative methodologies. This contrast is also very evident in Figure 7 in respect of the regional banks, although there is some evidence of a trend improvement in relative efficiency levels according to both the Production and Profit / Revenue-based approaches.

Finally, Figure 8 indicates that the results for the Trust banks provide an interesting contrast between the three alternative methodologies. It is once again evident that, according to the Intermediation approach, the Trust banks are relatively efficient on average with these mean efficiency scores being relatively stable over time. In contrast, both the Production and Profit / Revenue-based approaches show much lower mean efficiency levels (60 - 80 per cent and 40-70 per cent respectively) as well as a relatively high degree of temporal variation. This contrast between the alternative methodologies may help to explain the earlier finding by Drake and Hall (2003) that the Trust banks were highly efficient in the sense that the Intermediation approach (as used by Drake and Hall) clearly tends to overstate the relative efficiency of these banks when contrasted with the results emerging from the Profit / Revenue and Production approaches.

Figure 8 also indicates that, although the temporal variations in efficiency (in respect of the Revenue / Profit and Production approaches) are very similar after 1998, there are considerable differences evident in the earlier part of the sample period. The Profit / Revenue-based approach, for example, suggests that the Trust banks exhibited a sharp increase in mean efficiency from around 60 per cent to almost 85 per cent between 1995 and 1996, while the Production approach suggests that relative efficiency exhibits a modest deterioration over the same period. Similarly, the latter approach suggests that mean relative efficiency levels are improving 
between 1996 and 1998, while the Profit / Revenue-based approach reveals a relatively sharp decline in mean efficiency levels.

\section{CONCLUSIONS}

The analysis presented in this paper indicates that different methodological approaches to the specification of inputs and outputs in the context of non-parametric banking efficiency analysis can produce substantial differences in: sample mean efficiency levels; the dispersion of efficiency levels across the sample; temporal variations in sample mean and sectoral mean efficiency levels; and cross- sectoral rankings in terms of relative efficiency scores. This degree of dependence of empirical results on the particular methodological approach and model specification clearly raises potential question marks over the usefulness of relative efficiency analysis for policy purposes. The Intermediation- based results, for example, would suggest that the majority of Japanese banks are relatively efficient, as evident by the relatively high mean efficiency levels in most years. Furthermore, these results would suggest that there are only limited efficiency gains from merger / takeover activity (i.e., the market for corporate control), at least in terms of X-efficiency, given that the worst performing banks are typically only around 10 per cent less efficient than the average bank in the sample. As mentioned previously, however, this very limited degree of dispersion in the relative efficiency scores is somewhat surprising considering the turmoil experienced by the Japanese banking system in recent years, and given that we explicitly consider different bank sectors which might be expected, a-priori, to exhibit considerable differences in relative efficiency levels.

In contrast, the results obtained utilising the Production approach would suggest a clear policy agenda in the context of the evidence that, relative to the efficient reference set of banks, Japanese banks on average are only around 35 to 48 per cent efficient. Furthermore, the worst performing banks exhibit relative efficiency levels which are less than 10 per cent of those of the most efficient banks. Hence, these results suggest that the promotion of mergers / takeovers involving the least efficient banks could considerably enhance the stability and effectiveness of the Japanese banking system. These results also suggest that the bulk of the inefficiency resides in the MB2AR, Trust and Regional bank sectors (although the last mentioned have 
recorded a considerable improvement in mean efficiency since 1999), and hence that further policy responses should be directed primarily at these sectors, rather than the City and Coop bank sectors. ${ }^{18}$ Equally, however, if these Production-based relative efficiency results are to be believed, they represent an extremely powerful indictment of: corporate governance mechanisms; the market for corporate control; and the role of Government / regulators in Japan, in the sense that extremely inefficient banks can apparently co-exist alongside highly efficient institutions.

Finally, the Profit / Revenue-based relative efficiency results suggest that the mean level of inefficiency in the Japanese banking system is in the range $20-30 \%$, with some improvement in mean efficiency levels to just over $80 \%$ in recent years. This degree of mean inefficiency, however, combined with evidence that some banks exhibit relative efficiency levels as low as 35\%, again suggests that further policy efforts to promote the takeover or exit of the least efficient institutions is clearly warranted. With respect to the comparative performance of the different bank sectors, the most significant improvements in performance since 1998 / 99 have been recorded by the City, Coop and Regional bank sectors. Hence, as with the Production-based approach, these results would suggest that Japanese policymakers should focus their reform agenda on the MB2AR and Trust bank sectors.

\footnotetext{
18 The law passed in June 2004 allowing for pre-emptive capital injections into weak but solvent banks is a step in the right direction as it is aimed principally at both tiers of regional banks (Hall, 2004). And the official encouragement given to the recent formation of giant financial groups, typically involving a city bank and a trust bank (see Section 2.2), is further evidence that the Japanese authorities view appropriate consolidation as the solution to relative inefficiency in their banking system.
} 


\section{REFERENCES}

Akhigbe, A., and McNulty, J.E. (2003), "The Profit Efficiency of Small US Commercial Banks,” Journal of Banking and Finance, 27, 307-325.

Altunbas, Y., Liu, M-H., Molyneux, P. and Seth, R. (2000), “Efficiency and Risk in Japanese Banking,” Journal of Banking and Finance, 24, 1605-1628.

Altunbas, Y., Gardener, E.P.M., Molyneux, P., and Moore, B. (2001), "Efficiency in European Banking,” European Economic Review, 45, 10, 1931-1955.

Banker, R.D., Charnes, A. and Cooper, W.W. (1984), "Some Models for Estimating Technical and Scale Efficiencies in Data Envelopment Analysis.” Management Science, 30, 1078-1092.

Bank of Japan (2003), Review of Japanese Banks' Activities: Profits and Balance Sheets in Fiscal 2002, Tokyo, 29 August [<http://www.boj.or.jp>].

Basel Committee (2004), “The International Convergence of Capital Measurement and Capital Standards: A Revised Framework (Basel II)”, Basel, 26 June.

Benston, G.S. and Smith, C.W. (1976), “A Transactions Cost Approach to the Theory of Financial Intermediation,” Journal of Finance, 31, 215-231.

Berger, A.N., and Humphrey, D.B. (1991), “The Dominance of Inefficiencies Over Scale and Product Mix Economies in Banking,” Journal of Monetary Economics, 28, 117-148.

Berger, A.N., Leusner, H.J., and Mingo, J.J. (1997), “The Efficiency of Bank Branches,” Journal of Monetary Economics, 40, 141-162.

Berger, A.N., and Mester, L.J. (1997), "Inside the Black Box: What Explains

Differences in the Efficiencies of Financial Institutions?" Journal of Banking and Finance, 21, 895-947.

Berger, A.N. and Mester, L.J. (2003), "Explaining the Dramatic Changes in Performance of US Banks: Technological Change, Deregulation, and Dynamic Changes in Competition,” Journal of Financial Intermediation, 12, 57-95.

Bauer, P.W., Berger, A.N., Ferrier, G.D. and Humphrey, D.B. (1998), “Consistency Conditions for Regulatory Analysis of Financial Institutions: A Comparison of Frontier Efficiency Methods,” Journal of Economics and Business, 50, 85114. 
Cavallo, L., and Rossi, S.P.S. (2001), "Scale and Scope Economies in the European Banking Systems,” Journal of Multinational Financial Management, 11, 4-5, 515531.

Chaffai, M.E., Dietsch, M., and Lozano-Vivas, A. (2001), “Technological and Environmental Differences in the European Banking Industries,” Journal of Financial Services Research, 19, 147-162.

Charnes, A.W.W. Cooper, and Rhoades. E. (1978), "Measuring the Efficiency of Decision Making Units,” European Journal of Operational Research, 2, 429-444. Chu, S.F., and Lim, G.M. (1998), "Share Performance and Profit Efficiency of Banks in an Oligopolistic Market: Evidence from Singapore,” Journal of Multinational Financial Management, 8, 155-168.

Cooper, W.W., Seiford, L.M., and Tone, K. (2000), Data Envelopment Analysis, Kluwer Academic Publishers, Massachusetts, USA.

Cummins, J.D., Rubio - Misas, M. and Hongmin, Z. (2004), "The Effect of Organisational Structure on Efficiency: Evidence from the Spanish Insurance Industry”, Journal of Banking and Finance, 28, 3113 - 3150.

Drake, L.M. and Hall, M.J.B. (2003), “Efficiency in Japanese Banking: An Empirical Analysis,” Journal of Banking and Finance, 27, 891-917.

Drake, L.M, Hall, M.J.B, and Simper. R. (2005), “The Impact of Macroeconomic and Regulatory Factors on Bank Efficiency: A Non-Parametric Analysis of Hong Kong's Banking System,” forthcoming, Journal of Banking and Finance.

Drake, L.M., and Simper, R. (2002), “Economies of Scale in UK Building Societies: A Reappraisal Using an Entry/Exit Model,” Journal of Banking and Finance, 26, 2365-2382.

Drake, L.M., and Simper, R. (2003), “The Measurement of English and Welsh Police Force Efficiency: A Comparison of Distance Function Models,” European Journal of Operational Research, 147, 165-186.

Drake, L.M., and Weyman-Jones, T.G. (1996). "Productive and Allocative Inefficiencies in U.K. Building Societies: A Comparison of Non-parametric and Stochastic Frontier Techniques,” Manchester School of Economic and Social Studies, 114, 22-37.

Fare, R., Grosskopf, S., and Lovell, C.A.K. (1985), The Measurement of Efficiency Production, Kluwer Nijhoff, Boston, Mass. 
Farrell, M.J. (1957). “The Measurement of Productive Efficiency,” Journal of the Royal Statistical Association, Series A, CXX: 253-281.

Ferrier, G.D., and Lovell, C.A.K. (1990). "Measuring Cost Efficiency in Banking: Econometric and Linear Programming Evidence,” Journal of Econometrics, 46, 229-245.

Fukuyama, H. (1993), “Technical and Scale Efficiency of Japanese Commercial Banks: A Non-Parametric Approach, Applied Economics, 25, 1101-1112.

Hall, M.J.B. (1998a), Financial Reform in Japan: Causes and Consequences, Edward Elgar, Cheltenham

Hall, M.J.B. (1998b), "Financial Reform in Japan: "Big Bang””, Journal of International Banking Law,13, 2, 58-70

Hall, M.J.B. (1999a), “Current Banking Problems in Japan: How Serious Are They and How Might They Be Resolved?”, Research in Financial Services: Private and Public Policy, 11, 3-33.

Hall, M.J.B. (1999b), “Japan's Big Bang: The Likely Winners and Losers”, Journal of International Banking Law, 14, 7, 204-216.

Hall, M.J.B. (2000), "What is the Truth about the Scale of Japanese Banks' Bad Debts? Is the Situation Manageable?” Journal of Financial Services Research, 17, 69-91.

Hall, M.J.B. (2003a), “Banking Regulation and Supervision in Japan: Some Issues and Concerns,” Journal of Financial Regulation and Compliance, .11, 1, 45-59

Hall, M.J.B. (2003b), “The Resolution of the Japanese Banks' Bad Debt Problems: Can Koizumi Deliver on Time?” Loughborough University Banking Centre Research Paper, No.160/03, June.

Hall, M.J.B. (2004), "Recent Banking Sector Reforms in Japan: An Assessment," Economics Department Working Paper, No. ERP04-13, Loughborough University, September.

IMF (2003), “Japan: Financial System Stability Assessment and Supplementary Information,” IMF Country Report, No. 03/287, Washington, September.

Japanese Bankers' Association (2001), The Banking System in Japan, Tokyo, March Japanese Bankers' Association (2003), Japanese Banks, 2003, Tokyo.

Laeven, L. and Majnoni, G. (2003), "Loan Loss Provisioning and Economic Slowdowns: Too Much, Too Late?” Journal of Financial Intermediation, 12, 178197. 
Limi, A. (2004), "Banking Sector Reforms in Pakistan: Economies of Scale and Scope, and Cost Complementarities,” Journal of Asian Economics, 15, 507-528.

Lozano-Vivas, A., Pastor, J.A. and Pastor, J.M. (2002), “An Efficiency Comparison

of European Banking Systems Operating under Different Environmental Conditions,” Journal of Productivity Analysis, 18, 59-77.

Maudos, J. and Pastor, J.M. (2003), “Cost and Profit Efficiency in the Spanish Banking Sector (1985-1996): A Non-Parametric Approach,” Applied Financial Economics, 13, 1-12.

McAllister, P.H., and McManus, D. (1993), "Resolving the Scale Efficiency Puzzle in Banking,” Journal of Banking and Finance, 17, 389-405.

McKillop, D.G., Glass, J.C. and Morikawa, Y. (1996), “The Composite Cost Function and Efficiency in Giant Japanese Banks,” Journal of Banking and Finance, 20, 1651-1671.

Mertens, A., and Urga, G. (2001), "Efficiency, Scale and Scope Economies in the Ukrainian Banking Sector in 1998”, Emerging Markets Review, 2, 3, 292-308.

Pulley, L.B. and Braunstein, Y.M. (1992), “A Composite Cost Function for Multiproduct Firms with an Application to Economies of Scope in Banking," Review of Economics and Statistics, 74, 221-230.

Sealey, C., and Lindley, J.T. (1977), “Inputs, Outputs and a Theory of Production and Cost at Depository Financial Institutions,” Journal of Finance, 32, 1251-1266.

Tachibanaki, T., Mitsui, K. and Kitagawa, H. (1991), "Economies of Scope and Shareholding of Bank of Japan,” Journal of Japanese and International Economies, 5, 261-281.

Tone, K. (2001), “A Slacks-Based Measure of Efficiency in Data Envelopment Analysis,” European Journal of Operational Research, 130, 498-509.

Tortosa-Ausina, E. (2002), “Bank Cost Efficiency and Output Specification,” Journal of Productivity Analysis, 18, 199-222.

Tsionas, E.G., Lolos, S.E.G., and Christopoulos, D.K. (2003), “The Performance of the Greek Banking System in View of the EMU: Results from a Nonparametric Approach,” Economic Modelling, 20, 571-592. 
Table 1

Categorisation of Private Depository Institutions Operating in Japan as of 1.4.03*

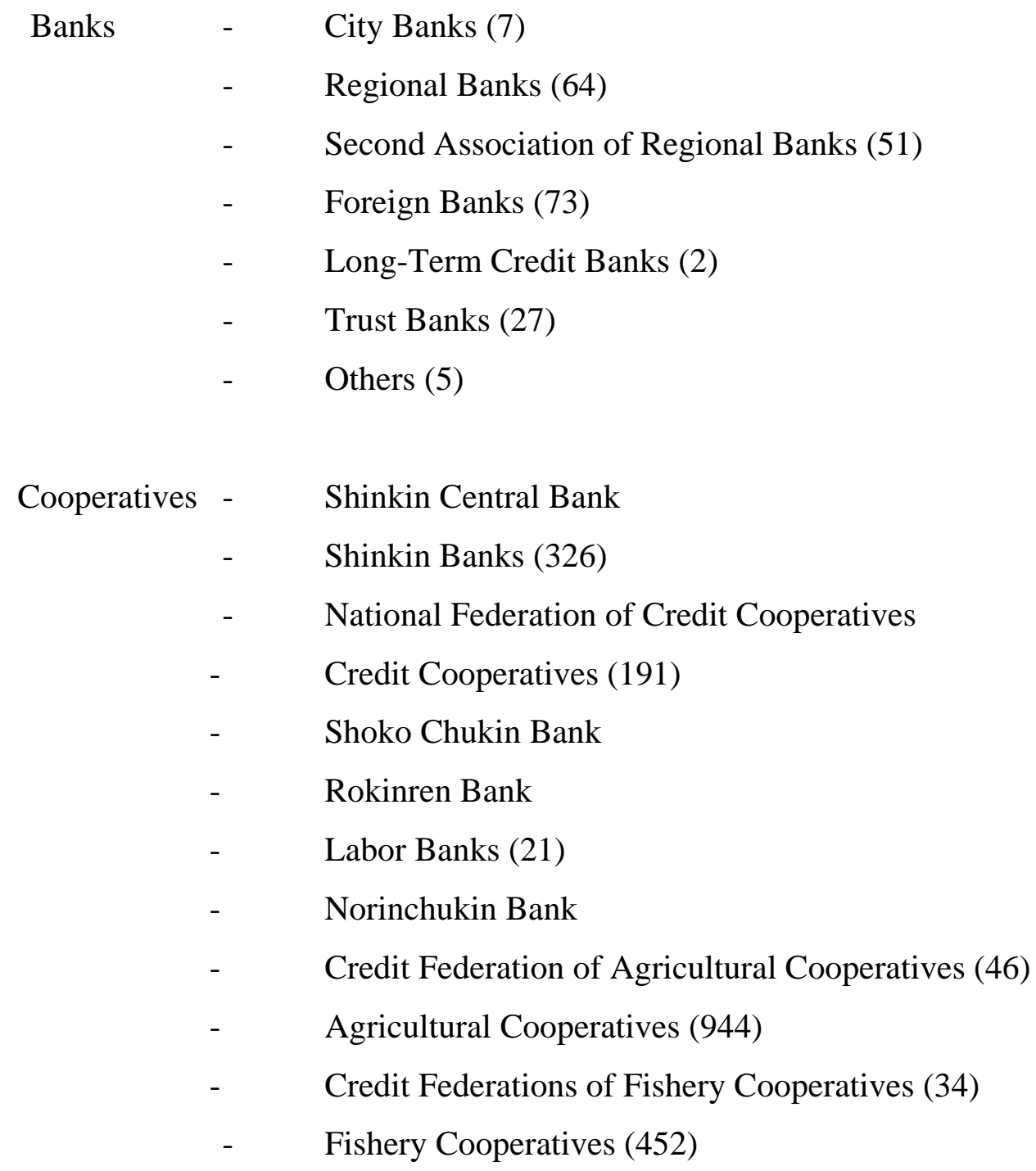

* $\quad$ Figures in parentheses represent the number of institutions in each category operating at 1 April 2003.

Source: Japanese Bankers' Association, 2003, p.1. 
Table 2.

Consolidation Amongst the Major Japanese Banks, 2000-2003.

\begin{tabular}{|c|c|c|c|}
\hline Merged Entities & Date of Merger & New Entity Formed & Latest Developments \\
\hline $\begin{array}{l}\text { Dai-Ichi Kangyo Bank }{ }^{(1)} \\
\text { Fuji Bank } \\
\text { Industrial Bank of Japan }^{(2)} \\
\text { Mizuho Trust }^{(3)} \\
\text { (jointly owned) }\end{array}$ & September 2000 & $\begin{array}{l}\text { Mizuho Holdings, } \\
\text { comprising: } \\
\text { Dai-Ichi Kangyo Bank }{ }^{(1)} \text {; } \\
\text { Fuji Bank }{ }^{(1)} \text {; } \\
\text { Industrial Bank of Japan }{ }^{(2)} \text {; } \\
\text { Mizuho Trust }^{(3)}\end{array}$ & $\begin{array}{l}\text { Mizuho Holdings, } \\
\text { comprising (at April 2002): } \text { Mizuho Bank }{ }^{(1)} \text {; } \\
\text { Mizuho Corporate Bank }^{(1)} \text {; } \\
\text { Mizuho Trust }^{(3)}\end{array}$ \\
\hline $\begin{array}{l}\text { Sakura Bank }{ }^{(1)} \\
\text { Sumitomo Bank }\end{array}$ & April 2001 & $\begin{array}{l}\text { Sumitomo Mitsui } \\
\text { Banking Corporation }\end{array}$ & $\begin{array}{l}\text { Sumitomo Mitsui } \\
\text { Financial Group, } \\
\text { comprising (at Dec. 2002): } \\
\text { Sumitomo Mitsui } \\
\text { Banking Corporation }^{(1)}\end{array}$ \\
\hline $\begin{array}{l}\text { Bank of Tokyo } \\
\text { Mitsubishi }^{(1)} \\
\text { - Tokyo Trust }^{(3)} \\
\text { Mitsubishi Trust }^{(4)} \\
\text { Nippon Trust }^{(4)}\end{array}$ & April 2001 & $\begin{array}{l}\text { Mitsubishi Tokyo } \\
\text { Financial Group, } \\
\text { comprising: } \\
\text { Bank of Tokyo- } \\
\text { Mitsubishi }{ }^{(1)} \text {; } \\
\text { Mitsubishi Trust }^{(4)} \text {; } \\
\text { Nippon Trust } \\
\text { Tokyo Trust }^{(3)}\end{array}$ & $\begin{array}{l}\text { Mitsubishi Tokyo Financial } \\
\text { Group, } \\
\text { comprising (at Oct. 2001): } \\
\text { Bank of Tokyo- } \\
\text { Mitsubishi }^{(1)} \text {; } \\
\text { Mitsubishi Trust }^{(4)}\end{array}$ \\
\hline $\begin{array}{l}\text { Sanwa Bank }^{(1)} \\
\text { Tokai Bank }^{(1)} \\
\text { - Tokai Trust } \\
\text { Toyo Trust } \\
\text { To }\end{array}$ & April 1001 & $\begin{array}{l}\text { UFJ Holdings, } \\
\text { comprising: } \\
\text { Sanwa Bank }^{(1)} \text {; } \\
\text { Tokai Bank }^{(1)} \text {; } \\
\text { Toyo Trust } \\
\text { Tokai Trust }^{(3)}\end{array}$ & $\begin{array}{l}\text { UFJ Holdings, } \\
\text { comprising (at Jan. 2002): }_{\text {UFJ Bank }}^{(1)} \text {; } \\
\text { UFJ Trust }^{(4)}\end{array}$ \\
\hline $\begin{array}{l}\text { Daiwa Bank Holdings, } \\
\text { comprising (at Dec. 2001): } \\
\text { Daiwa Bank }^{(1)} \text {; } \\
\text { Kinki Osaka Bank }^{(5)} \text {; } \\
\text { Nara Bank }^{(5)} \text {; } \\
\text { Asahi Bank }{ }^{(1)} \text {; } \\
\text { Asahi Trust }\end{array}$ & $\begin{array}{l}\text { March } 2002 \\
\text { (effective } \\
\text { October 2002) }\end{array}$ & $\begin{array}{l}\text { Resona Holdings, } \\
\text { comprising: } \\
\text { Daiwa Bank }^{(1)} \text {; } \\
\text { Asahi Bank }^{(1)} ; \\
\text { Kinki Osaka Bank }^{(5)} \text {; } \\
\text { Nara Bank }^{(5)} ; \\
\text { Daiwa Trust }^{(4)}\end{array}$ & $\begin{array}{l}\text { Resona Holdings, } \\
\text { comprising (at March } \\
\text { 2003): } \\
\text { Resona Bank }^{(1)} \text {; } \\
\text { Saitama Resona Bank }{ }^{(1)} \text {; } \\
\text { Kinki Osaka Bank }{ }^{(5)} \text {; } \\
\text { Nara Bank }^{(5)} \text {; } \\
\text { Resona Trust }^{(4)}\end{array}$ \\
\hline \multicolumn{4}{|l|}{ Notes: } \\
\hline
\end{tabular}

Source: Japanese Bankers' Association, 2003, p.15. 
Table 3.

Summary Statistics for Japanese Banks’ Inputs and Outputs.

\begin{tabular}{|c|c|c|c|c|}
\hline & Mean & $\begin{array}{l}\text { Standard } \\
\text { deviation }\end{array}$ & Minimum & Maximum \\
\hline \multicolumn{5}{|l|}{ Inputs } \\
\hline Total Deposits (I) & 50905.77 & 113920.01 & 1124.13 & 880622.86 \\
\hline $\begin{array}{l}\text { Total Operating Expenses } \\
\text { (I) }\end{array}$ & 609.18 & 1178.07 & 9.86 & 9726.20 \\
\hline Total Fixed Assets (I) & 603.56 & 1774.87 & 0.81 & 17597.59 \\
\hline $\begin{array}{l}\text { Total Provisions (I), (PR), } \\
\text { (P) }\end{array}$ & 580.13 & 1196.08 & 0.76 & 10836.06 \\
\hline $\begin{array}{l}\text { Total Non-interest } \\
\text { Expenses (PR), (P) }\end{array}$ & 468.25 & 851.06 & 6.83 & 7245.95 \\
\hline $\begin{array}{l}\text { Total Other Operating } \\
\text { Expenses (PR), (P) }\end{array}$ & 140.93 & 392.94 & 0.00 & 4291.49 \\
\hline \multicolumn{5}{|l|}{ Outputs } \\
\hline$\overline{\text { Total Loans (I), (P) }}$ & 35680.93 & 79226.96 & 135.77 & 688526.55 \\
\hline $\begin{array}{l}\text { Total Other Earning } \\
\text { Assets (I), (P) }\end{array}$ & 16995.38 & 42653.69 & 15.91 & 359026.10 \\
\hline $\begin{array}{l}\text { Net Commission, Fee and } \\
\text { Trading Income (I), (PR), } \\
\text { (P) }\end{array}$ & 166.44 & 231.21 & 0.001 & 2158.23 \\
\hline $\begin{array}{l}\text { Other Operating Income } \\
(\mathrm{I}),(\mathrm{PR}),(\mathrm{P})\end{array}$ & 163.14 & 472.47 & 0.80 & 5463.87 \\
\hline Net Interest Income (PR) & 708.78 & 1356.93 & 8.34 & 11739.23 \\
\hline Total Deposits $(\mathrm{P})$ & 50937.29 & 113916.75 & 1124.13 & 880622.86 \\
\hline
\end{tabular}


Table 4.

SBM Efficiency Scores of the Japanese Banking System.

\begin{tabular}{|c|c|c|c|c|c|c|c|c|}
\hline \multicolumn{9}{|c|}{ Intermediation Methodology } \\
\hline & 1995 & 1996 & 1997 & 1998 & 1999 & 2000 & 2001 & 2002 \\
\hline City & 98.75 & 99.68 & 98.82 & 98.93 & 99.25 & 98.79 & 97.48 & 98.37 \\
\hline COOP & 99.26 & 99.59 & 99.46 & 98.63 & 99.48 & 100 & 100 & 100 \\
\hline MB2AR & 96.28 & 96.34 & 95.95 & 92.02 & 95.42 & 95.73 & 94.82 & 94.69 \\
\hline Regional & 95.67 & 96.43 & 95.94 & 95.32 & 95.35 & 95.89 & 95.33 & 95.83 \\
\hline Trust & 96.72 & 96.61 & 98.50 & 97.31 & 97.73 & 98.94 & 96.86 & 98.30 \\
\hline Minimum & 91.61 & 87.02 & 85.86 & 58.82 & 89.69 & 87.46 & 88.64 & 84.22 \\
\hline Average & 96.27 & 96.68 & 96.38 & 95.53 & 95.85 & 96.25 & 95.39 & 95.71 \\
\hline \multicolumn{9}{|c|}{ Production Methodology } \\
\hline & 1995 & 1996 & 1997 & 1998 & 1999 & 2000 & 2001 & 2002 \\
\hline City & 66.36 & 57.68 & 55.42 & 62.98 & 61.95 & 75.90 & 75.38 & 83.73 \\
\hline COOP & 82.89 & 59.50 & 75.86 & 53.91 & 53.31 & 74.51 & 91.15 & 90.89 \\
\hline MB2AR & 41.41 & 40.14 & 40.83 & 35.40 & 34.55 & 38.41 & 35.88 & 38.19 \\
\hline Regional & 34.16 & 34.94 & 37.12 & 34.60 & 29.66 & 35.77 & 40.79 & 48.68 \\
\hline Trust & 42.64 & 37.25 & 47.74 & 46.04 & 51.31 & 68.74 & 46.24 & 57.27 \\
\hline Minimum & 13.42 & 9.76 & 14.57 & 7.63 & 9.55 & 8.56 & 11.28 & 10.18 \\
\hline Average & 40.86 & 39.32 & 41.39 & 37.82 & 35.38 & 41.85 & 41.34 & 47.64 \\
\hline \multicolumn{9}{|c|}{ Profit / Revenue Methodology } \\
\hline & 1995 & 1996 & 1997 & 1998 & 1999 & 2000 & 2001 & 2002 \\
\hline City & 81.43 & 81.91 & 70.99 & 71.31 & 82.98 & 85.90 & 84.61 & 86.47 \\
\hline COOP & 93.23 & 84.54 & 92.82 & 87.92 & 82.80 & 88.20 & 94.00 & 100 \\
\hline MB2AR & 80.55 & 81.32 & 77.16 & 72.70 & 79.49 & 80.07 & 75.55 & 77.29 \\
\hline Regional & 76.36 & 79.25 & 75.92 & 71.26 & 77.15 & 76.92 & 77.05 & 83.59 \\
\hline Trust & 60.39 & 84.64 & 63.84 & 57.46 & 62.32 & 74.17 & 63.05 & 78.17 \\
\hline Minimum & 49.85 & 43.45 & 34.95 & 32.64 & 35.03 & 46.43 & 36.48 & 43.19 \\
\hline Average & 77.96 & 80.71 & 75.65 & 71.34 & 77.54 & 78.90 & 76.57 & 81.45 \\
\hline $\begin{array}{l}\text { The bank c } \\
\text { banks, "Coo } \\
\text { the Second } \\
\text { term Credit } \\
\text { Foreign ban } \\
\text { (http://www }\end{array}$ & . & 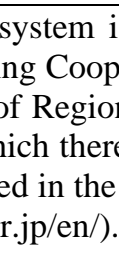 & sar & ongt & in $\mathrm{T}, \mathrm{bl}$ & ith & $\begin{array}{l}\text { repre } \\
\text { Mem } \\
\text { Neith } \\
\text { ationa }\end{array}$ & $\begin{array}{l}\text { ting City } \\
\text { Banks of } \\
\text { he Long- } \\
\text { d, nor the } \\
\text { sociation }\end{array}$ \\
\hline
\end{tabular}


Figure 1

Japanese Bank Efficiency - Intermediation Methodology

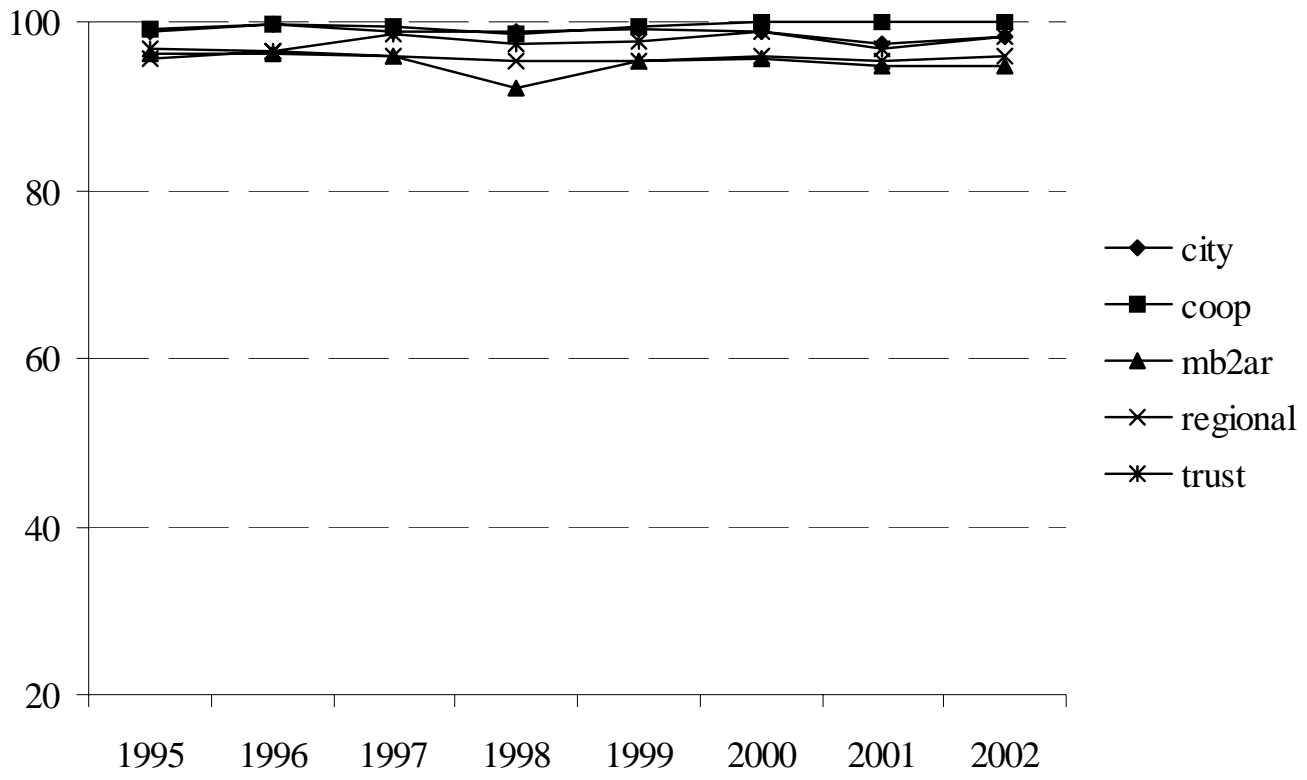

Figure 2.

Japanese Bank Efficiency - Profit / Revenue Methodology

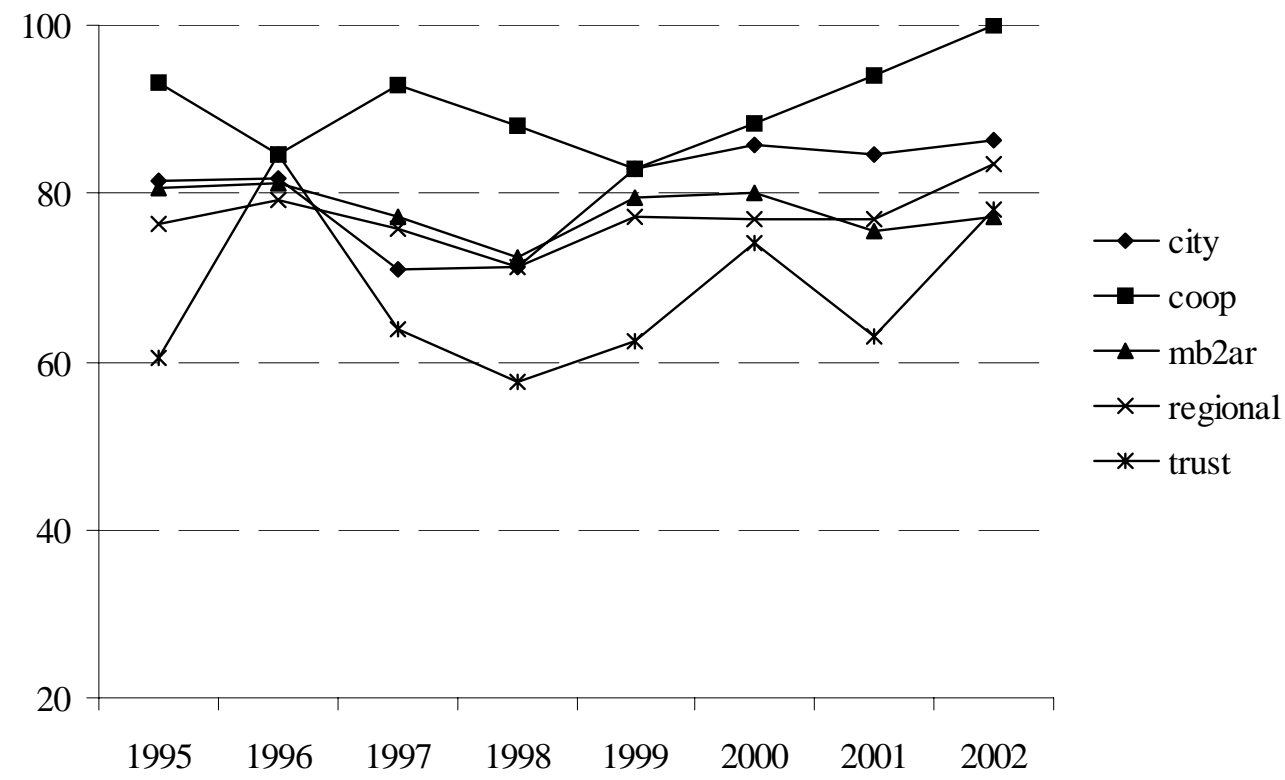


Figure 3

Japanese Bank Efficiency - Production Methodology

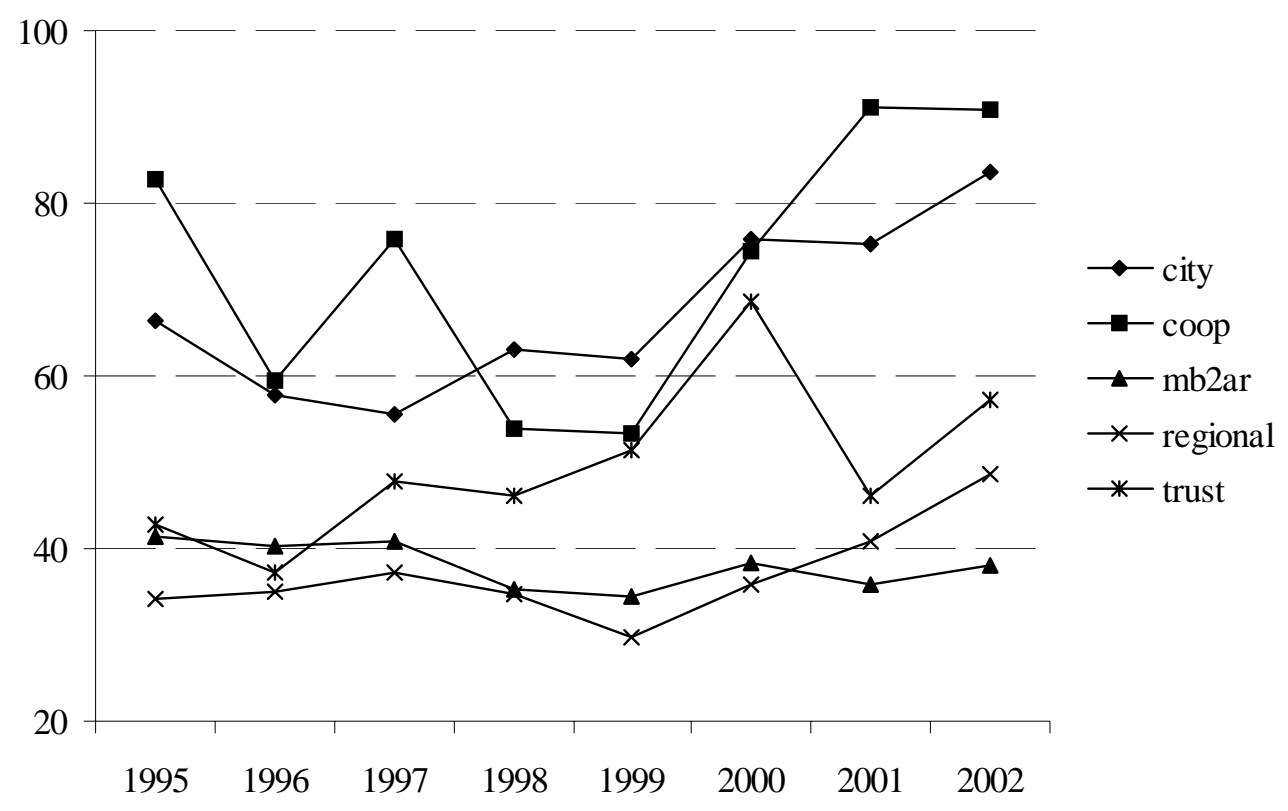

Figure 4.

Comparison of Bank Modelling Methodologies: City Banks

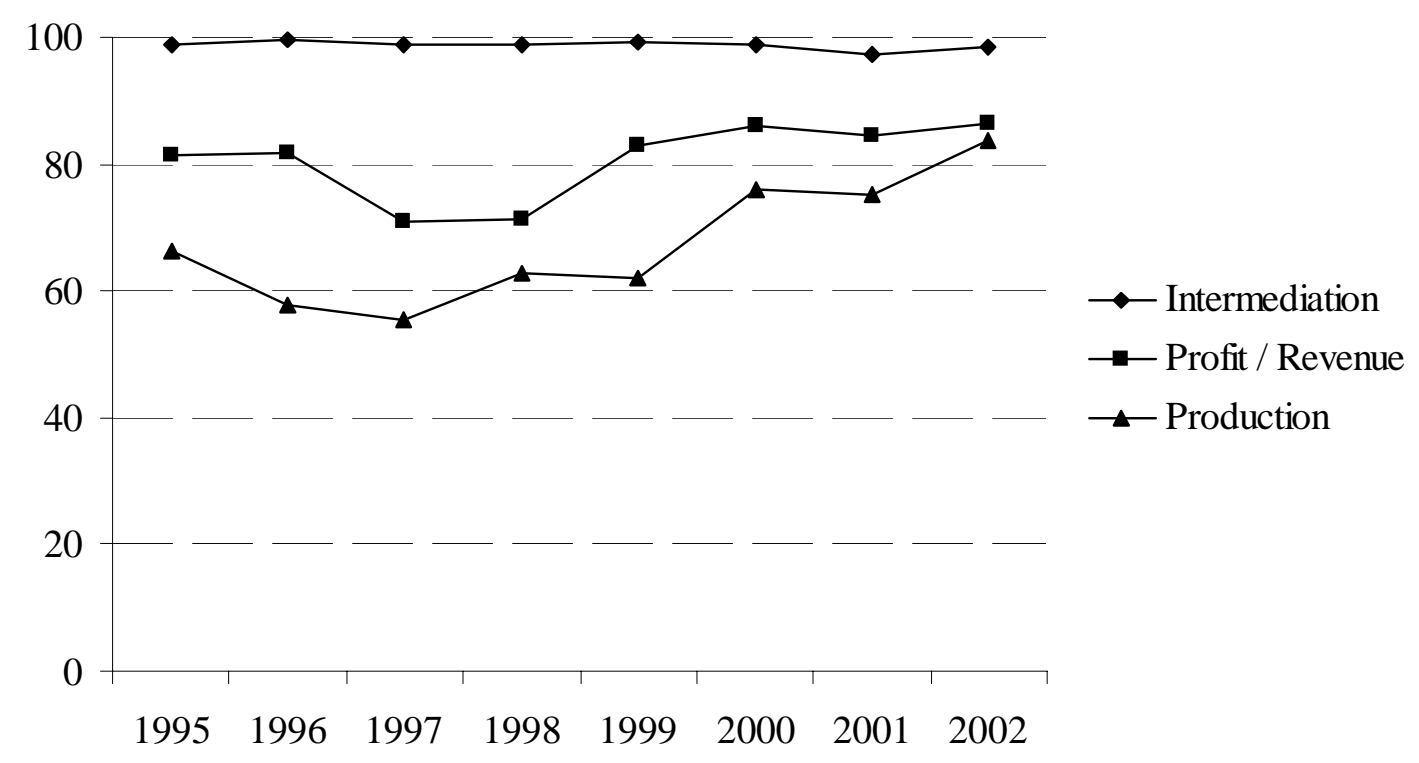


Figure 5

Comparison of Bank Modelling Methodologies: Coop Banks

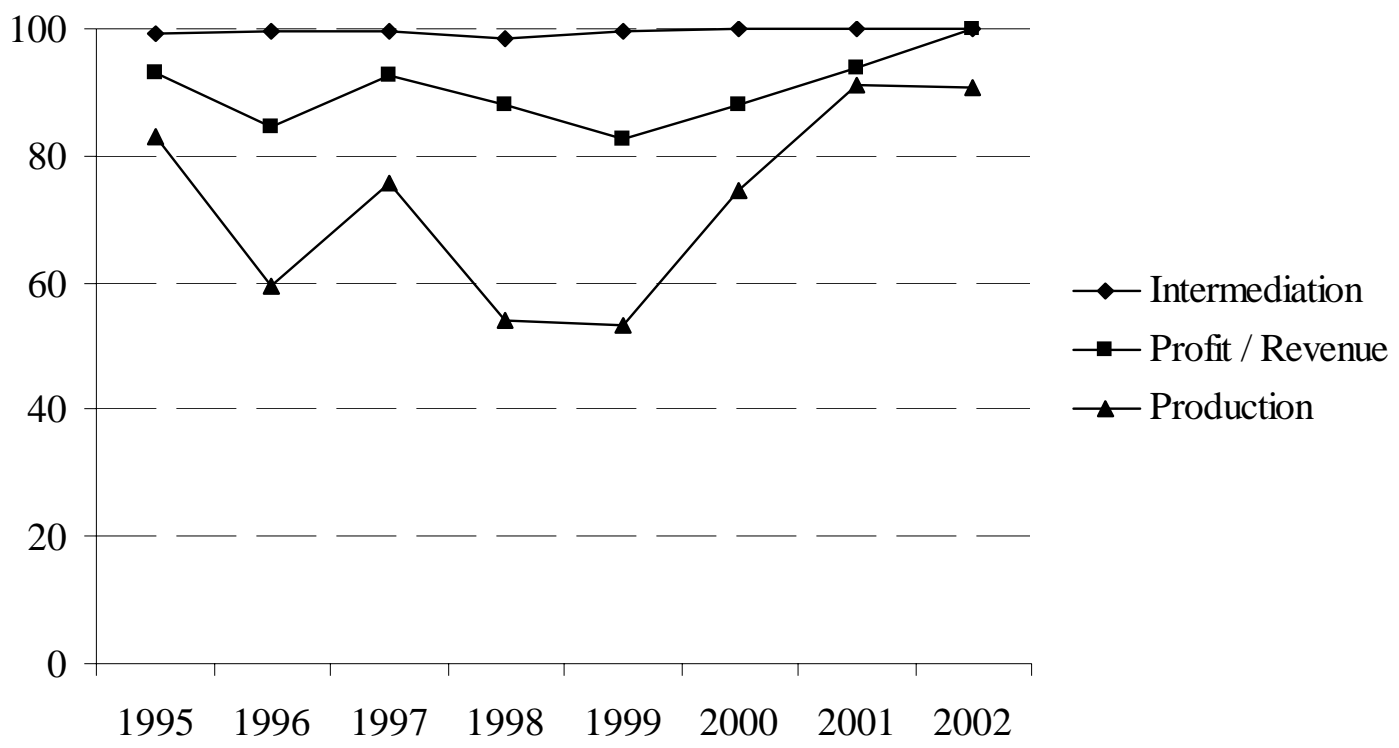

Figure 6

Comparison of Bank Modelling Methodologies: MB2AR Banks

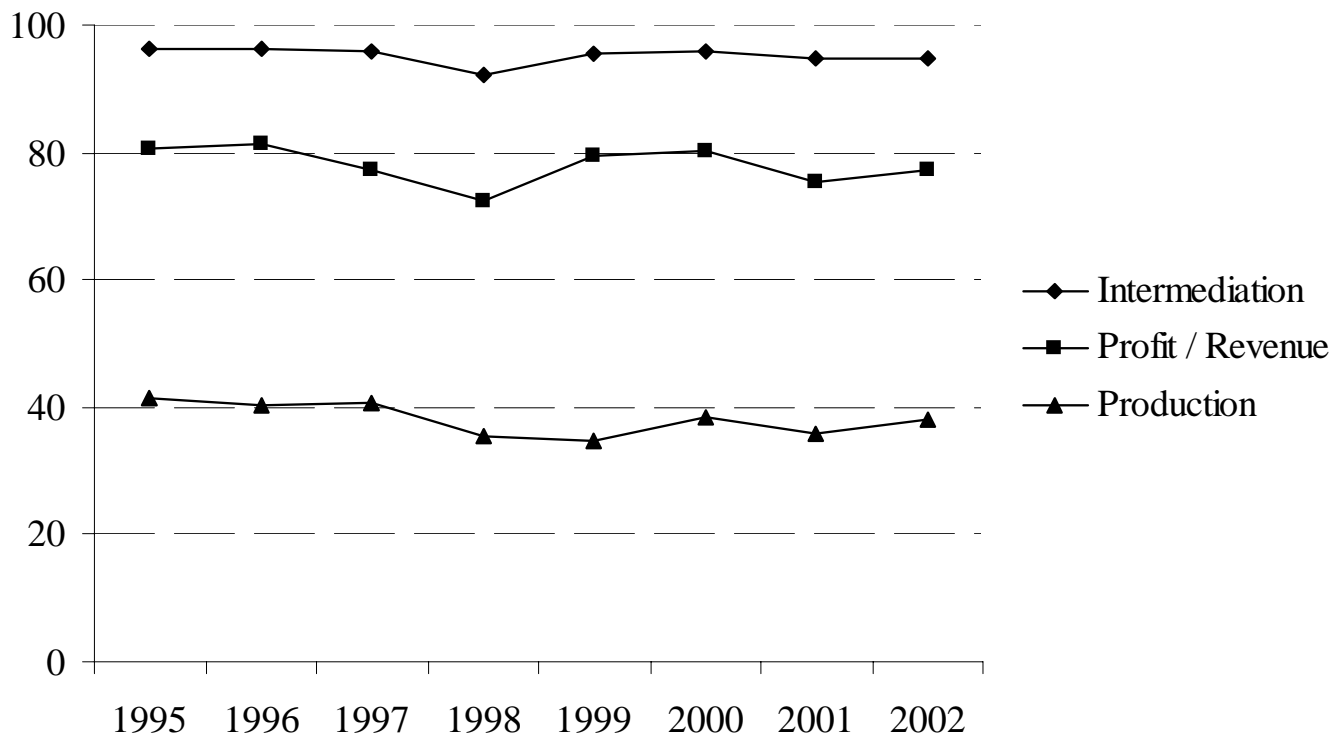


Figure 7

Comparison of Bank Modelling Methodologies: Regional banks

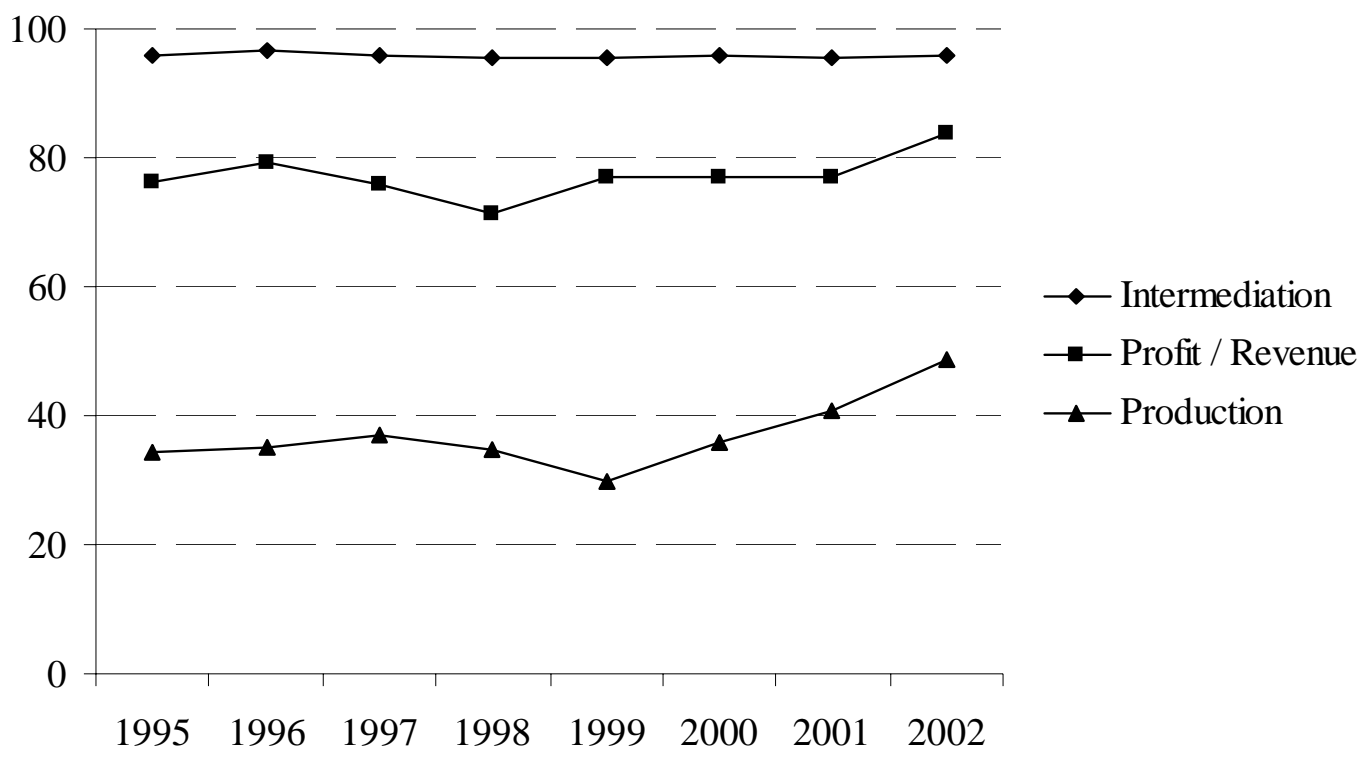

Figure 8

Comparison of Bank Modelling Methodologies: Trust Banks

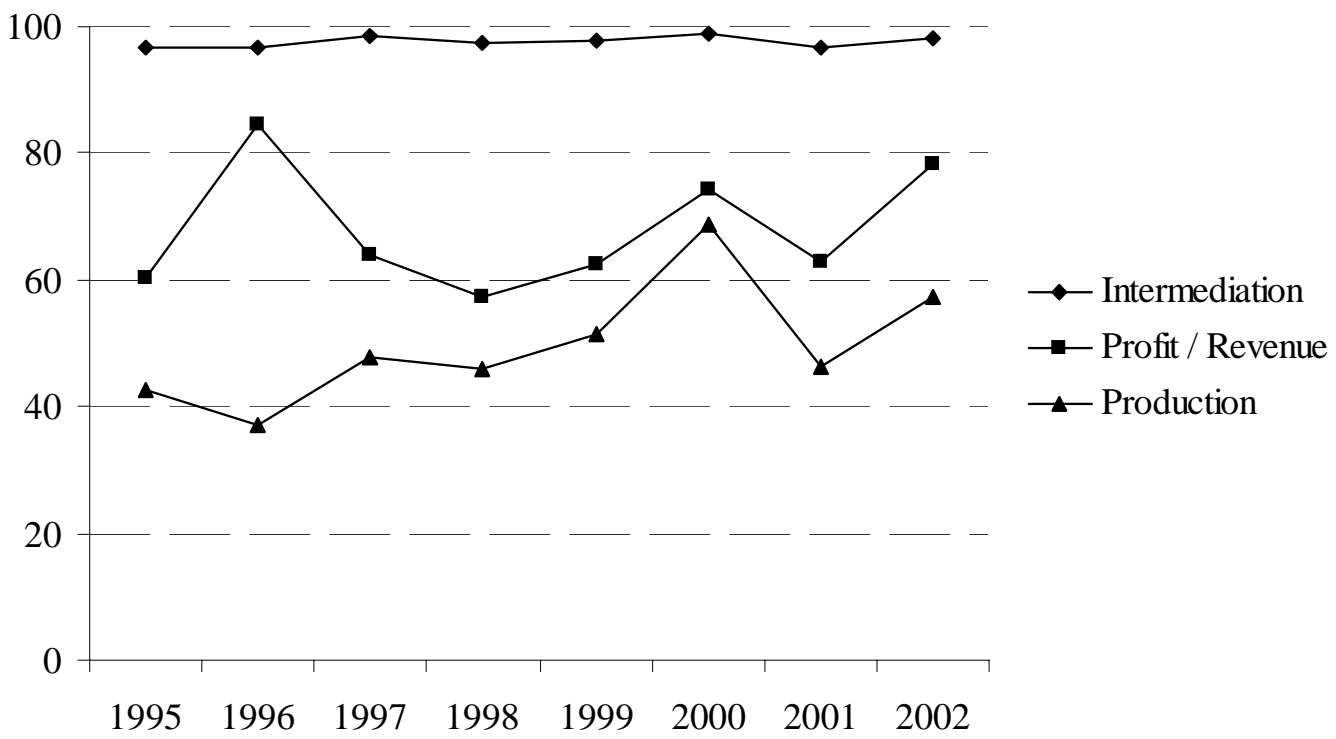

